\title{
Effect of Integrated Nitrogen Management on the Yield and Economy of Wheat Variety WH 1184
}

\author{
Said Asif Sarbaz ${ }^{1}$, Satish Kumar ${ }^{2}$, Suresh Kumar ${ }^{3}$, Kautilya Chaudhary ${ }^{4}$, Jogander Kumar ${ }^{5}$ \\ Vinod Kumar Malik ${ }^{6}$ \\ ${ }^{1}$ Department of Agriculture, Irrigation and Livestock Nangarhar, (DAIL - N). Ministry of Agriculture Afghanistan \\ 2, 3, 4, Department of Agronomy, CCS Haryana Agricultural University, Hisar, Haryana 125004 \\ ${ }^{5}$ Department of Agricultural Economics
}

${ }^{6}$ Department of Plant Pathology, CCS Haryana Agricultural University, Hisar Haryana 125004

\begin{abstract}
The field experiment was conducted at wheat research farm of CCS Haryana Agriculture University during Rabi season of 2019 - 20 to study the economics of wheat under integrated nitrogen management. The experiment was laid out in randomized block design with three replications containing 16 treatments combination i.e. T1 - Control; T2 - 100\% RDN through urea; T3 - 100\% RDN through FYM; T4 - 100\% RDN through vermicompost; T5 - 50\% RDN through urea+ 50\% RDN through FYM; T6 - 50\% RDN through urea+ 50\% RDN through vermicompost; T7 - 25\% RDN through urea+ 75\% RDN through FYM; T8 - 25\% RDN through urea 75\% RDN through vermicompost; T9 - 100\% RDN through urea + Azotobacter; T10 - 100\% RDN through FYM + Azotobacter; T11 $100 \%$ RDN through vermicompost + Azotobacter; T12 - 50\% RDN through urea+ 50\% RDN through FYM + Azotobacter; T13 - 50\% RDN through urea+ 50\% RDN through vermicompost + Azotobacter; T14 - 25\% RDN through urea+ 75\% RDN through FYM + Azotobacter; T15 - 25\% RDN through urea+ 75\% RDN through vermicompost + Azotobacter; T16 - Azotobacter. On the basis of one year data, application of $100 \%$ nitrogen nutrition through chemical fertilizer (urea) with seed treatment of Azotobacter produce 30.7 percent higher grain and 24.9 percent higher straw yield of wheat variety WH 1184 over control treatment. Application of $100 \%$ nitrogen nutrition through vermicompost with seed treatment of Azotobacter incurred highest cost of cultivation (66629 Rs/ha). The significantly higher gross return of wheat was obtained with the application of $100 \%$ nitrogen nutrition of chemical fertilizer along with seed treatment of Azotobacter (107923 Rs/ha) and B: C ratio (2.98) was achieved by nitrogen nutrition of 100\% RDN through chemical fertilizer (urea) with seed treatment of Azotobacter being at par with nitrogen nutrition of $100 \%$ only chemical fertilizer (urea).
\end{abstract}

Keywords: integrated nitrogen management, FYM, vermicompost, Azotobacter.

\section{Introduction}

Wheat (Triticum aestivum L.) is one of the world's leading cereal crop, which can be grown in wide range of altitudes and latitudes. Wheat is one of the good sources of carbohydrates and unique protein, which is consumed as human food as well as animal feed. It is the staple food of nearly $35 \%$ of world population. Globally wheat was grown in around 215.45 million hectares during 2018 - 19, holding the highest position in acreage among all other crops with yearly production of 370.84 million tonnes with the yield of $3390 \mathrm{~kg} / \mathrm{ha}$ (USDA, 2020). Wheat cultivation has also been sign of green revolution, self - sufficiency in food and sustained production (Alam et al., 2013). India is the second largest producer of wheat next to China, which produces about 107.59 million tons of wheat from an area of 29.6 million hectare with an average productivity of $3508 \mathrm{~kg}$ ha

${ }^{1}$. The states which produce significant amount of wheat are Haryana, Uttar Pradesh, Punjab, Rajasthan, Gujarat, Madhya Pradesh, Bihar and Maharashtra. Haryana produces 12.57 million tons of wheat from 2.55 million hectare in year 2018 - 19, with an average productivity of $4925 \mathrm{~kg} \mathrm{ha-1}$ (Anonymous, 2020). Wheat is cultivated principally in two seasons in the world viz., winter and spring. Winter wheat is cultivated in temperate zones viz., Europe, USA and Russian Federation etc. Winter wheat matures in 240 - 300, days while spring wheat matures in 100 - 150 days depending upon temperature Wheat can be grown from below sea level depth up to 5000 meter altitude and in areas where the precipitation prevails between $300-1130 \mathrm{~mm}$ annually (Bhardwaj et al., 2010). As it is a thermo - sensitive long day crop, therefore, temperature is a major determinant of growth and productivity of wheat. The optimum temperature regime during growing season of wheat crop ranges in between $20-22{ }^{\circ} \mathrm{C}$ at sowing, $16-22{ }^{\circ} \mathrm{C}$ at tillering till grain filling stage and slowly temperature rises to $40{ }^{\circ} \mathrm{C}$ at harvesting time (Sharma, 2000). To overcome the problem of nutrient deficiency and to increase wheat yield, the farmers are using chemical fertilizers. However the chemical fertilizers are costly and the small farmers cannot afford to use these fertilizers in appropriate amount and balanced proportion. Under such condition integrated use of chemical and organic fertilizer can play an important role to maintain soil fertility and crop productivity. Nitrogen is one of the most important nutrients applied to crop for higher yield and quality, but its balanced use is a key point for healthy environment and higher land effectiveness which can be attain through integrated nitrogen management (Iqbal et al., 2012). Biofertilizers are a good approach to increase crop productivity. Nowadays, the biofertilizers are used to supply the important nutrients to the plant and significantly increase its productivity. These are eco - friendly, cost effective, provides the natural environment to the plant, boost the protection system of the plant, and protect the plant from drought, acidity, and other unfavorable conditions (Nosheen et al., 2020). The fertilizer use has increased year after year, but it mainly consists of nitrogenous fertilizers. The ratio of NPK consumption in India is 6.92: 2.57: 1 as compared to 
the normal 4: 2: 1 (vermic Survey, 2004 - 05). This erratic fertilizer use pattern may result in decreasing food grain production trend. In some areas, wheat productivity either remains stagnated or showed declining trend during last few years. This is mainly due to increased salinity, water logging, deficiency of secondary and micronutrients, decrease in organic carbon and less use of organic inputs, Above all, population of beneficial micro - organisms in soil has also reduced due to chemical based agriculture. Thus for sustainable growth in productivity of wheat growing areas, it is important to increase the use of organic manures, which has become an important part of the concept, known as organic farming. Moreover, due to growing heath consciousness, the demand for high quality food produced with minimum chemical inputs is growing rapidly these days. Plant nutrition is the most important factor influencing grain yield, nutrient uptake and quality of a crop. What is an exhaustive crop which requires special nutritional care through chemical fertilizer, it is not possible to supply every nutrient in natural and balance form. Therefore, an integrated approach to plant nutrient management gained momentum and importance in recent years. The objective of this approach is effective, sensible and economic use of all main sources of plant nutrients in an integrated manner so as to maximize/optimize yield of a crop or a cropping system without any adverse effect on the agroecosystem. It has therefore, becomes necessary to develop an integrated plant nutrient management system, involving the use of inorganic fertilizers on one hand and FYM/vermicompost along with biofertilizers as an organic source on the other for maximizing /optimizing wheat productivity. Moreover, bulky organic manures, being low in nutrient content and less availability, are not able to fulfill the need of nutrients of intensive cropping system. Therefore, to have sustainable crop productivity, integration of chemical fertilizers with various concentrated sources of plant origin and their scientific agronomic management are important.

\section{Materials and Methods}

The field experiment was conducted at wheat research farm of CCS Haryana Agriculture University during Rabi season of 2019 - 20 to study the economics of wheat under integrated nitrogen management. The experiment was laid out in randomized block design with three replications containing 16 treatments combination i. e T1 - Control; T2 $100 \%$ RDN through urea; T3 - 100\% RDN through FYM; T4 - 100\% RDN through vermicompost; T5 - 50\% RDN through urea+ 50\% RDN through FYM; T6 - 50\% RDN through urea+ 50\% RDN through vermicompost; T7 - 25\% RDN through urea+ 75\% RDN through FYM; T8 - 25\% RDN through urea $75 \%$ RDN through vermicompost; T9 $100 \%$ RDN through urea + Azotobacter; T10 - 100\% RDN through FYM + Azotobacter; T11 - 100\% RDN through vermicompost + Azotobacter; T12 - 50\% RDN through urea+ 50\% RDN through FYM + Azotobacter; T13 - 50\% RDN through urea+ 50\% RDN through vermicompost + Azotobacter; T14 - 25\% RDN through urea+ 75\% RDN through FYM + Azotobacter; T15 - 25\% RDN through urea+ $75 \%$ RDN through vermicompost + Azotobacter; T16 - Azotobacter. The initial status of soil fertility was 130: 17: $250 \mathrm{~kg}$ NPK ha - 1 with 0.37 percent organic carbon. The wheat variety WH 1184 used for sowing at the rate of 120 $\mathrm{kg} / \mathrm{ha}$. Both the FYM and vermicompost were analyzed for available nitrogen and were made to percent RDN. The FYM and vermicompost were broadcasted as per treatments. Half dose of nitrogen through urea was applied before sowing as per treatments, along with full dose of $\mathrm{P}, \mathrm{K}$ and $\mathrm{Zn}$, and second half dose after first irrigation. All the agronomic operation were equally done for all the treatments. The only differences among the treatments were the rate and source of nitrogen nutrition. The costs of cultivation were calculated on the basis of the price given by Directorate of Wheat Research Farm, CCSHAU. The gross return, net return and benefit cost ration was worked out as per standard formulas.

\section{Results and Discussion}

The grain yield of a variety is genetically governed but had an impact of nutrient supply and environmental conditions during the crop growth period. Among different nutrients, nitrogen is an essential element and plays an important role in the crop growth yield attributing parameters viz. effective tillers, number of grain and 1000 grain weight plays a significant role in wheat production. Nutrition of crop with $100 \%$ RDN through urea produced 28.6 and 27.8 per cent higher grain yield as compared to nutrition through FYM and vermicompost, respectively. This might be due to quick release of nitrogen in sufficient amount by urea as compared to FYM or vermicompost as these organic sources require some time for decomposition and mineralization which led to insufficient supply of nitrogen to crop plants. Similar findings were reported by Mubarak and Singh, 2011. Seed treatment with Azotobacter increased the wheat grain yield to the tune of 3.29 per cent as compared to control which might be due to more release/availability of nitrogen to crop plants with seed treatment of Azotobacter. Kumar, A.2020 has also reported improvement of wheat yield with Azotobacter seed treatment. Improvement in yield attributing character i.e. effective tillers grains per spike and 1000 grain weight contributed to higher grain yield of wheat in Azotobacter treatment. Decrease in proportion of nitrogen through urea to $50 \%$ and substitution with $50 \%$ RDN through FYM and vemicompost reduced the grain yield by 21.43 and 22.24 percent as compared to $100 \%$ RDN nutrition through urea. Higher LAI with higher proportion of inorganic nitrogen resulted in more production of photosynthesis which ultimately contributed to the higher grain yield of wheat. Kumar, et al.2020 have also reported that decrease in proportion of inorganic nitrogen source to $75 \%$ and substitution of $25 \%$ RDN through FYM or vermicompost decreased the grain yield of wheat. Inoculation with Azotobacter in either of the proportion of inorganic and organic nitrogen i.e. 50: 50 or 25: 75 improved the grain yield of wheat compared to no inoculation. Synergistic effect of Azotobacter inoculation at different proportion of inorganic

Through vermicompost + Azotobacter though produced statistically at par grain yield but numerically higher as compared with $100 \%$ RDN through FYM + Azotobacter.

Cost of cultivation of different treatment was worked out and given in Table 1. The cost of cultivation was found higher in treatment receiving $100 \%$ RDN through 
vermicompost with or without Azotobacter. Reduction in proportion of $\mathrm{N}$ nutrition through vermicompost reduced the cost of cultivation. The cost of cultivation of wheat with $\mathrm{N}$ nutrition through FYM was lower in all treatment combination as compared to treatments involving vermicompost. Decreasing in proportion of RDN increased the cost of cultivation. Cost of cultivation with treatment involving $100 \%$ RDN nutrition with urea was - 26.99 and 83.63 percent lower than alone application of FYM and vermicompost, respectively. Lowest cost of cultivation was recorded in control treatment and organic nitrogen sources has also been reported by Verma et al, 2015 and Kumar, et al $2020.100 \%$ RDN

\section{Conclusion}

Among different sources of nutrient, 100\% RDN nutrition through urea produced significantly higher grain and straw yield as compared to nutrition through FYM or vermicompost. Yield increase was to the tune of 28.6 and 27.8 percent in urea nutrition over FYM and vermicompost nutrition. Among different in integrated nutrient combination maximum yield was in 50\% RDN through urea $+50 \%$ RDN through vermicompost + Azotobacter.

Among different integrated treatments, higher net return (Rs 71696) and B: C ratio 2.10 was recorded with treatment receiving $50 \%$ RDN through urea $+50 \%$ RDN through FYM + Azotobacter. Higher per unit of nitrogen of vermicompost led of lower net return and B: C ratio as compared to FYM receiving treatments.

\section{References}

[1] Alam, M. P., Kumar, S., Ali, N., Manjhi, R. P., Kumari, N., Lakra, R. K., \& Izhar, T. (2013). Performance of wheat varieties under different sowing dates in
Jharkhand. Journal of Wheat Research, 5 (2): 61 - 64.

[2] Anonymous, (2020). Economic survey of Haryana 2019 $-20$.

[3] Bhardwaj, V., Yadav, V., \& Chauhan, B. S. (2010). Effect of nitrogen application timings and varieties on growth and yield of wheat grown on raised beds. Archives of Agronomy and Soil Science, 56 (2): 211 222.

[4] Economic survey of Haryana 201920.

[5] Economic survey.2004 - 05. Published by Ministry of Finance, Govt of India. P.182.

[6] Iqbal, J., Hayat, K., Hussain, S., Ali, A., and Bakhsh, M. A. A. H. A. (2012). Effect of seeding rates and nitrogen levels on yield and yield components of wheat (Triticum aestivum L.). Pakistan Journal of Nutrition, 11 (7): 53

[7] Kumar, A., Tiwari, U. S., Kumar, V., Kumar, N., and Yadav, A. K. (2020). Assessment of the integrated nutrient management effects on yield attributes and yield of wheat cv. PBW - 550. Plant Archives, 20 (2): $282-285$

[8] Mubarak, T., \& Singh, K. N. (2011). Nutrient management and productivity of wheat (Triticum aestivum L.) -based cropping systems in temperate zone. Indian journal of Agronomy, 56 (3), 176 - 181.

[9] Nosheen, S, Ajmal, L song, Y. Microbes as Biofertilizers, a potential Approach for sustainable crop production. Sustainability 2020, 13, 1868.

[10] USDA 2020. Word Agriculture Production. Foreign Agricultural Service United States Department of Agriculture. Circular Series, WAP 6 - 20, June 2020.

[11] Verma, V. K., Singh, V., Choudhary, S., Tripathi, A. K., and Srivastava, A. K. (2015). Effect of organic manures and microbial inoculants superimposed over inorganic fertilizers on production and profitability of wheat (Triticum Aestivum L). Current Advances in Agricultural Sciences, 7 (2): 129 - 132.

Table 1: Yield (kg/ha) and Economics of different treatments (Rs/ha)

\begin{tabular}{|c|c|c|c|c|c|c|c|c|}
\hline Treatments & $\begin{array}{c}\text { Grain } \\
\text { yield } \\
(\mathrm{Kg} / \mathrm{ha})\end{array}$ & $\begin{array}{c}\text { Straw } \\
\text { yield } \\
(\mathrm{Kg} / \mathrm{ha})\end{array}$ & $\begin{array}{c}\text { Biological } \\
\text { Yield } \\
(\mathrm{kg} / \mathrm{ha})\end{array}$ & $\begin{array}{c}1000 \\
\text { seed } \\
\text { wt }(\mathrm{g})\end{array}$ & \begin{tabular}{|c|}
$\begin{array}{c}\text { Cost of } \\
\text { cultivation } \\
(\mathrm{Rs} / \mathrm{ha})\end{array}$ \\
\end{tabular} & $\begin{array}{l}\text { Gross } \\
\text { returns } \\
\text { (Rs/ha) }\end{array}$ & $\begin{array}{l}\text { Net } \\
\text { returns } \\
\text { (Rs/ha) }\end{array}$ & B: $\mathrm{C}$ \\
\hline $\mathrm{T}_{1}$ : Control & 3911 & 6333 & 10744 & 31.7 & 34525 & 75129 & 40604 & 2.18 \\
\hline $\mathrm{T}_{2}: 100 \% \mathrm{RDN}$ through urea & 5600 & 8365 & 13965 & 42.0 & 36272 & 107223 & 70951 & 2.96 \\
\hline $\mathrm{T}_{3}: 100 \%$ RDN through FYM & 4000 & 6752 & 10752 & 34.0 & 46063 & 76976 & 30913 & 1.67 \\
\hline $\mathrm{T}_{4}: 100 \% \mathrm{RDN}$ through vermicompost & 4044 & 6769 & 10814 & 34.3 & 66609 & 77794 & 11185 & 1.17 \\
\hline $\mathrm{T}_{5}: 50 \%$ RDN through urea+ 50\% RDN through FYM & 4400 & 6853 & 11253 & 38.0 & 41168 & 84387 & 43219 & 2.05 \\
\hline $\begin{array}{c}\mathrm{T}_{6}: 50 \% \mathrm{RDN} \text { through urea+ 50\% RDN through } \\
\text { vermicompost }\end{array}$ & 4355 & 6643 & 10998 & 38.0 & 51441 & 83454 & 32013 & 1.62 \\
\hline $\mathrm{T}_{7}: 25 \%$ RDN through urea+75\% RDN through FYM & 4177 & 6589 & 10767 & 35.0 & 43615 & 80151 & 36536 & 1.84 \\
\hline $\begin{array}{c}\mathrm{T}_{8}: 25 \% \mathrm{RDN} \text { through urea+ } 75 \% \mathrm{RDN} \text { through } \\
\text { vermicompost }\end{array}$ & 4222 & 6631 & 10854 & 35.3 & 59025 & 81000 & 21975 & 1.37 \\
\hline $\mathrm{T}_{9}: 100 \% \mathrm{RDN}$ through urea + Azotobacter & 5640 & 8424 & 14064 & 42.5 & 36292 & 107988 & 71696 & 2.98 \\
\hline $\mathrm{T}_{10}: 100 \%$ RDN through FYM +Azotobacter & 4133 & 6948 & 11081 & 35.0 & 46083 & 79521 & 33438 & 1.73 \\
\hline $\mathrm{T}_{11}: 100 \%$ RDN through vermicompost + Azotobacter & 4266 & 7050 & 11317 & 35.3 & 66629 & 82019 & 15390 & 1.23 \\
\hline $\begin{array}{l}\mathrm{T}_{12}: 50 \% \text { RDN through urea+ } 50 \% \text { RDN through FYM } \\
+ \text { Azotobacter }\end{array}$ & 4502 & 6953 & 11456 & 39.3 & 41188 & 86313 & 45125 & 2.10 \\
\hline $\begin{array}{c}\mathrm{T}_{13}: 50 \% \text { RDN through urea+ } 50 \% \text { RDN through } \\
\text { vermicompost }+ \text { Azotobacter }\end{array}$ & 4688 & 7151 & 11840 & 40.3 & 51461 & 89835 & 38374 & 1.75 \\
\hline $\begin{array}{c}\mathrm{T}_{14}: 25 \% \text { RDN through urea+ } 75 \% \text { RDN through FYM } \\
+ \text { Azotobacter }\end{array}$ & 4211 & 6642 & 10853 & 36.3 & 43635 & 80803 & 37168 & 1.85 \\
\hline $\begin{array}{c}\mathrm{T}_{15}: 25 \% \text { RDN through urea+75\% RDN through } \\
\text { vermicompost+Azotobacter }\end{array}$ & 4271 & 6708 & 10979 & 36.3 & 59045 & 81940 & 22895 & 1.39 \\
\hline $\mathrm{T}_{16}:$ Azotobacter & 4044 & 6945 & 10990 & 32.3 & 34545 & 77882 & 43337 & 2.25 \\
\hline
\end{tabular}




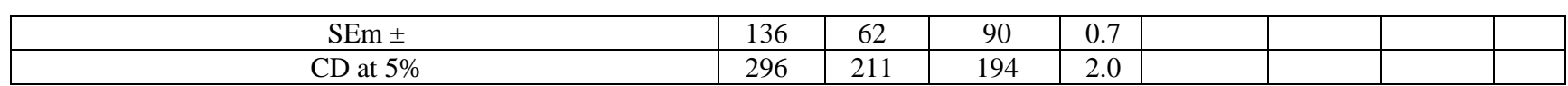

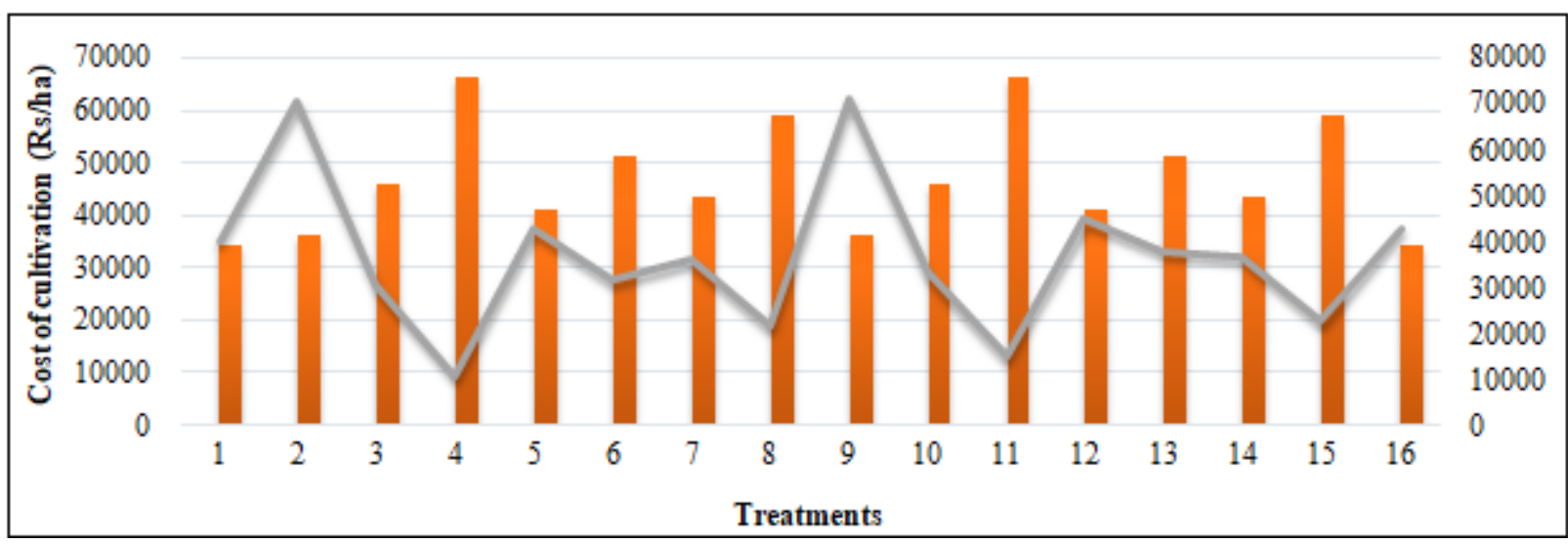

Figure 1: Net returns (Rs/ha) and cost of cultivation (Rs/ha) of wheat 